\title{
Investigation of Canine Distemper Virus Infection in Dogs in the Antalya Province
}

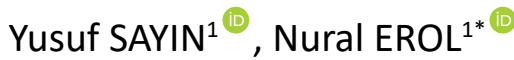 \\ ${ }^{1}$ Department of Virology, Faculty of Veterinary Medicine, Aydin Adnan Menderes University, Aydin, Turkey
}

\begin{abstract}
A B S T R A C T
Canine distemper virus (CDV) is one of the most prevalent infectious agents causing severe clinical symptoms among canids. Communal life-habitat, for example, clinics, dog-shelters, or rural areas, is critical in terms of the transmission dynamics of CDV. In this study, the blood serum samples from 92 dogs, which were brought to the rehabilitation center and private veterinary clinics in Antalya with various internal medical problems, were examined for CDV infection. The sampled dogs were unvaccinated and aged 2 to 12 months. Samples were tested using a commercial immunochromatographic rapid test for detection of CDV-antigens and Enzyme Linked Immunosorbent Assays (ELISA) for detection of CDV-specific Immunoglobulin G (IgG) and Immunoglobulin M (IgM).

The most common clinical findings in the 92 dogs sampled were mucopurulent discharge in the eye (45.65\%), nasal hyperkeratosis (35.87\%), nasal mucopurulent discharge (25\%), cough (13.04\%), diarrhea (8.70\%), and fatigue (6.52\%). It was observed that clinical findings were more intense in the early reconvalescent period. 5.43\% (5/92) of the samples examined by the immunochromatographic rapid test were positive. The positivity rates of IgG and IgM antibodies by ELISA were 80.43\% (74/92) and 94.56\% (87/92), respectively. Totally, 91 (98.91\%) of the 92 dogs tested by ELISA for IgG and IgM antibodies were positive for one or both antibodies, and one (1.09\%) was negative for both antibodies. In conclusion, it was determined that CDV infection is actively circulating in the Antalya province and poses a risk to unvaccinated dogs in the region.
\end{abstract}

Keywords: Antibody, Antigen, Canine distemper virus, ELISA

\section{Antalya'daki Köpeklerde Canine Distemper Virus (CDV) Enfeksiyonunun Araştırılması}

\section{ÖZET}

Canine distemper virusu (CDV), köpek türleri arasında ciddi klinik semptomlara neden olan en yaygın enfeksiyöz ajanlardan biridir. Klinikler, köpek barınakları veya kırsal alanlar gibi ortak yaşam alanları, CDV'nin bulaşma dinamikleri açısından kritik öneme sahiptir. Bu araştırmada Antalya ilindeki Rehabilitasyon merkezine ve özel veteriner kliniklerine çeşitli dahili sağlık problemleriyle getirilen, toplam 92 adet köpekten alınan kan örnekleri CDV enfeksiyonu yönünden incelendi. Köpekler, 2-12 aylık ve aşısızlardı. Örnekler CDV-antijenlerinin saptanması için ticari immunokromatografik hızlı test kiti ile, CDV spesifik immunoglobulin G (IgG) ve immunoglobulin M (IgM) antikorların saptanması için ise ticari Enzyme Linked Immunosorbent Assay (ELISA) kitleri ile test edildi.

Örneklenen 92 köpekte en fazla gözlenen klinik bulgular sırasıyla gözde mukopurulent karakterde akıntı (\%45,65), nasal hiperkeratoz (\%35,87), nasal mukopurulent akıntı (\%25), öksürük $(\% 13,04)$, ishal $(\% 8,70)$, halsizlik $(\% 6,52)$ olarak kaydedildi. Klinik bulguların erken rekonvalesan dönemde daha yoğun olduğu gözlendi. İmmunokromatografik hızlı test ile incelenen numunelerden \%5,43 (5/92)'ü pozitif bulundu. ELISA ile IgG antikorları yönünden pozitiflik oranı \%80,43 (74/92) olarak bulundu. ELISA ile IgM antikorları yönünden pozitiflik oranı ise \%94,56 (87/92) olarak tespit edildi. Genel olarak, IgG ve IgM antikorlarının tespiti için ELISA ile test edilen 92 köpekten 91 tanesi (\%98,91) IgG veya IgM antikorlarından biri veya her ikisi yönünden pozitif, 1 (\%1,09) tanesi ise her iki antikor yönünden negatif bulundu. Sonuç olarak, Antalya ilinde CDV enfeksiyonunun yaygın bir şekilde dolaşımda olduğu ve bölgedeki aşısız köpekler için risk oluşturduğu belirlendi. 


\section{Introduction}

Canine Distemper Virus (CDV) is a negative singlestranded and non-segmented RNA virus belonging to the species Canine Morbillivirus, the genus Morbillivirus, the subfamily Orthoparamyxovirinae, and the family Paramyxoviridae (ICTV, 2020). CDV, which is one of the most important viruses for dogs, causes respiratory, digestive, and nervous system disorders and death in young dogs. Besides being a multisystemic infection, diagnosis and treatment of the disease can be difficult because it causes severe immunosuppression and prepares the ground for other diseases (Elia et al., 2015; Sabatino, 2016).

Distemper infection is endemic in many parts of the world. The incidence of the disease is very low in developed countries (Sabatino, 2016). CDV can infect dogs of all ages, but puppies aged 0-6 months are especially susceptible (Çalışkan, 2007; Latha et al., 2007b).

For the control and prevention of infection, it is necessary to know the incidence, prevalence rates, and risk factors in the region. The most basic preventive measure against CDV is vaccination. Since the early 1960 s, the routine use of modified live virus vaccines has been done to struggle against the virus. Vaccination programs are important in order to prevent the transmission of infection and to ensure adequate immunity (Budaszewski et al., 2016).

Numerous clinical parameters and laboratory analyses are recommended for the definitive diagnosis of distemper. However, the unpredictable and variable disease course, such as duration of viremia, clinical findings, and deficient or delayed humoral or cellular immune responses, hinders the correct diagnosis of distemper and makes the collection of appropriate samples for laboratory confirmation very important. Meanwhile, given that the infection is highly contagious, detection of CDV from different biological samples is essential for determining the correct treatment and necessary precautions (Elia et al., 2015; Sabatino, 2016). It has been reported that the infection causes high mortality and morbidity, especially in unvaccinated puppies, and poses a serious threat to all unvaccinated house dogs and stray dogs (Elia et al., 2015; Zacharias et al., 2016).

According to studies conducted in Turkey, canine distemper virus infection is a disease that constantly increases and becomes widespread over the years (Çalışkan and Burgu, 2007; Esin, 2013; Saltık, 2018). In this study, it was aimed to determine the current status of CDV infection, which seriously threatens the health of dogs, both owned and stray dogs brought to private veterinary clinics and the rehabilitation center in Antalya province. In the study, clinical findings in dogs were monitored and evaluated with laboratory (test for the presence of antigen, IgG and IgM) results.

\section{Materials and Methods}

For this study, blood serum samples taken for diagnostic purposes from a total of 92 unvaccinated dogs under the age of one with various internal health problems in the province of Antalya in May 2019 were used. 28 of these animals were brought to private veterinary clinics, and 64 of them were dogs, either brought to a street animal rehabilitation center in Muratpaşa-Antalya or housed there due to health problems. It was known that all of the animals sampled had a connection with the street and could roam freely. Information about the sampled dogs (age, sex, health status, clinical findings, lifestyle, etc.) was recorded. Three of the animals ranged from 2-6 months, and 89 of them were between $6-12$ months. It was recorded that 30 of the dogs were males and 62 of them were females. The sampled animals were randomly selected. Permission was obtained from the Akdeniz University Animal Experiments Local Ethics Committee for the study (Protocol no: 2017.08.005 Decision No: 74).

In order to be tested for CDV-antigen and IgG and IgM antibodies against CDV from blood samples taken into kaolin tubes by the veterinarian under appropriate conditions in the clinical environment, their serums were separated and stored at $-20^{\circ} \mathrm{C}$.

The 92 blood serums from dogs were tested for the CDV antigen by a commercially available rapid test kit with an immunochromatography principle (CDV Ag-Antigen Rapid Test kit ${ }^{\circledR}$, BioNote, Inc., Republic of Korea). The CDV specific IgG and IgM antibodies in all serums were investigated by commercially available indirect ELISA kits (Distemper IgG and IgM Ab ELISA, Biopronix Agrolabo, Italy). All the tests were performed according to the manufacturer's instructions.

\section{Results}

Dogs sampled in the study had clinically suspicious or significant signs of CDV infection. The clinical findings recorded in dogs are listed in Table 1.

The rates of clinical findings observed in dogs sampled in thestudyareasfollows: $45.65 \%$ (42/92) eye mucopurulent discharge, $35.87 \%$ (33/92) nasal hyperkeratosis, $25 \%$ (23/92) nasal mucopurulent discharge, $13.04 \%$ (12/92) cough, $8.70 \%$ (8/92) diarrhea, 6.52\% (6/92) fatigue, $1.09 \%(1 / 92)$ skin scaling, dermatitis around the eyes, anorexia, vomiting, myoclonus and hair loss (Table 1 ). While only 1 of the above-mentioned clinical findings was observed in 57 dogs, 26 dogs had two clinical findings and 9 had three of the above-mentioned clinical findings.

In the study, CDV antigen was investigated with a commercial immunochromatographic rapid test kit and CDV specific IgG and IgM antibodies were investigated with commercial ELISA kits in 92 blood serums taken from dogs for diagnostic purposes. Whereas the antigen positivity rate was $5.43 \%(5 / 92)$, the seropositivity rates for IgG and IgM antibodies were $80.43 \%$ (74/92) and 
Table 1. The positivity rates of IgG and IgM antibodies according to the clinical findings of the dogs

\begin{tabular}{|l|c|c|c|c|c|}
\hline \multirow{2}{*}{ Clinical Finding } & \multicolumn{2}{|c|}{ IgG } & \multicolumn{2}{c|}{ IgM } \\
\cline { 2 - 6 } & $\mathbf{N} *(\%)$ & $\begin{array}{c}\text { IgG positive } \\
\text { animals }\end{array}$ & $* * \%$ & $\begin{array}{c}\text { IgM positive } \\
\text { animals }\end{array}$ & $* * \%$ \\
\hline Eye Mucopurulent Discharge & $42(45.65)$ & 31 & 73.81 & 39 & 92.86 \\
\hline Nasal Hyperkeratosis & $33(35.87)$ & 30 & 90.91 & 32 & 96.97 \\
\hline Nasal Mucopurulent Discharge & $23(25)$ & 17 & 73.91 & 22 & 95.65 \\
\hline Cough & $12(13.04)$ & 11 & 91.67 & 12 & 100 \\
\hline Diarrhea & $8(8.70)$ & 7 & 87.5 & 7 & 87.5 \\
\hline Weakness & $6(6.52)$ & 5 & 83.33 & 6 & 100 \\
\hline Cachexia & $5(5.43)$ & 4 & 80 & 4 & 80 \\
\hline Flaking of the Skin & $1(1.1)$ & 0 & 0 & 1 & 100 \\
\hline Myoclonus & $1(1.09)$ & 1 & 100 & 1 & 100 \\
\hline Hair Loss & $1(1.09)$ & 1 & 100 & 1 & 100 \\
\hline Dermatitis Around the Eyes & $1(1.09)$ & 1 & 100 & 1 & 100 \\
\hline Anorexia & $1(1.09)$ & 1 & 100 & 1 & 100 \\
\hline Vomiting & $1(1.09)$ & 1 & 100 & 1 & 100 \\
\hline
\end{tabular}

$\mathrm{N}$ : Number of animals showing clinical signs out of 92 dogs

*\%: Percentage of animals with each observed clinical signs

**\%: Percentage rates of IgG or IgM positivity in animals for each clinical signs

Table 2. Distribution of IgG and IgM antibodies in sampled dogs

\begin{tabular}{|c|c|c|c|c|}
\hline \multicolumn{2}{|c|}{} & \multicolumn{2}{|c|}{ IgG } & \multirow{2}{*}{ Total } \\
\cline { 3 - 4 } \multicolumn{2}{|c|}{} & Positive (\%) & Negative (\%) & \\
\hline \multirow{3}{*}{$\operatorname{lgM}$} & Negative (\%) & $1(\% 18.48)$ & $4(\% 4.35)$ & $\mathbf{5}(\% 5.43)$ \\
\cline { 2 - 5 } & Positive (\%) & $17(18.48)$ & $70(\% 76.09)$ & $\mathbf{8 7}(\% 94.56)$ \\
\hline \multicolumn{2}{|c|}{ Total } & $\mathbf{1 8 ( \% 1 9 . 5 6 )}$ & $\mathbf{7 4 ( \% 8 0 . 4 3 )}$ & $\mathbf{9 2}$ \\
\hline
\end{tabular}

\subsection{6\% (87/92), respectively.}

Of the samples tested by ELISA for the detection of IgG and IgM antibodies, 98.91\% (91/92) were positive for one or both IgG and IgM antibodies, and $1.09 \%$ (1/92) were negative for both antibodies. It was determined that $76.09 \%$ (70/92) of these dogs were positive for both antibodies (IgM and IgG antibodies). While $18.48 \%$ (17/92) of the sampled dogs were positive only for IgM antibodies (negative for IgG), 4.35\% (4/92) were found to be positive only for IgG antibodies (negative for IgM) (Table 2).

According to the method based on the presence of IgG and IgM antibodies defined by Richmann et al. (2017) and used for CDV infection by Saltik and Kale (2020), clinical periods of infection were evaluated as acute (IgG-, $\lg M+)$, early convalescent ( $\lg \mathrm{G}+, \lg \mathrm{M}+)$, late convalescent $(\operatorname{lgG}+, \lg M-)$, and no infection (IgG-, IgM-). Table 3 shows the number of animals based on their infection status. In animals, clinical symptoms were most common in the early convalescent period (Table 4).

In the samples taken from the owned dogs brought to the private clinic, the positivity rates for $\lg M$ and
IgG antibodies were detected at $89.29 \%(25 / 28)$ and $75 \%$ (21/28), respectively. In these dogs, antigen positivity was found at a rate of $3.57 \%(1 / 28)$, in the test performed with the rapid test kit. In 64 dogs from the rehabilitation center, a positivity rate of $96.87 \%(62 / 64)$ was found for IgM antibodies, whereas it was found to be $82.81 \%$ (53/64) positive in terms of IgG antibodies. Antigen positivity was detected in $6.25 \%(4 / 64)$ of 64 dogs examined with the rapid test kit.

\section{Discussion}

This study was carried out to determine the status of CDV infection in stray dogs in the rehabilitation center in Antalya and in owned dogs brought to private veterinary clinics. In the study, the clinical findings in dogs and the test results for the presence of antigen, IgG, and IgM were evaluated.

The detection of specific IgM antibodies has an important place in the diagnosis of CDV infections (Latha et al., 2007a), and it seems to be the ideal method for the serological diagnosis of acute distemper infections (von Messling et al., 1999). Saltik and Kale (2020) argue that the diagnosis gives highly reliable results by 
Table 3. Number of animals in infection periods according to the presence of IgG and IgM antibodies against CDV

\begin{tabular}{|l|c|c|c|c|}
\hline Infection periods & IgG & IgM & Animal / n & \% \\
\hline Acute & - & + & $77 / 92$ & $70 / 92$ \\
\hline Early Convalescent & + & + & $4 / 92$ & 76.097 \\
\hline Late Convalescent & + & - & $1 / 92$ & 4.35 \\
\hline No Infection & - & - & 1.09 \\
\hline
\end{tabular}

testing IgG and IgM antibodies at the same time. Their study showed that detection of the canine distemper virus specific antibodies by the ELISA is quick and safe in naturally infected dogs. Consequently, this method is very useful for the pre-diagnosis of the disease when evaluated together with the clinical symptoms. In their research on 50 dogs, they found positivity rates for IgG and IgM antibodies of $94 \%(47 / 50)$ and $58 \%(29 / 50)$, respectively. Latha et al. (2007a) detected seropositivity for the presence of IgM antibodies by ELISA in 34 of the blood sera of 70 vaccinated dogs. Blixenkrone-Møller et al. (1993) collected blood serum from 66 vaccinated and unvaccinated dogs that were clinically suspicious and found $74 \%(49 / 66)$ IgM antibody positivity in these serums by ELISA. In the samples collected from the conjunctiva, they obtained antigen-positive results with a rate of $42 \%(27 / 65)$ by indirect immunofluorescence test. In this study, it was found to be $94.6 \%$ (87/92) positive for the presence of IgM antibodies in ELISA, whereas antigenpositivity was $5.43 \%$ (5/92) in the rapid test.

Çalışkan and Burgu (2007) found IgG-positivity at $41 \%$. Esin (2013) reported that 70 of 116 (60.34\%) dogs were IgG-positive in the ELISA. Saltık (2018) found $94 \%$ positive for IgG antibodies in his research. In this study, it was determined that $80.43 \%$ (74/92) of 92 dogs were positive for IgG antibodies in the ELISA.

In this study, 91 (98.91\%) of the 92 samples tested with ELISA for detection of CDV-specific IgG and IgM antibodies were positive for either or both of these IgG or IgM antibodies, and 1 sample (1.09\%) for both antibodies was found negative. This means that $98.91 \%$ of dogs are newly or previously infected with CDV. The reason for the high rate of up to $99 \%$ in the presented study can be shown that the sampling was done only in dogs with clinical findings. However, the fact that $99 \%$ of the animals brought to the clinic and rehabilitation center within 1 month show antibody positivity for distemper gives information that the prevalence of the infection has reached serious levels when the results of this study are compared with previous studies. It should also be noted that the dogs sampled in the study were chosen randomly from among dogs with internal health complaints, not because they were particularly suspicious of CDV. This shows that CDV infection is seriously prevalent in the region.

Depending on the severity of the infection and the viral strain, the virus-specific IgMs could be found from the 6-8th day up to the 3rd month following the infection (Appel and Summers, 1999; Barrett, 1999). Based on the literature information and the data obtained in the study, it is thought that acute CDV-infection is not shortlived in Antalya, but is widespread and effective for more than 3 months, and even endemic.

Richmann et al. (2017) reported the infection process as acute, early reconvalescent, and late reconvalescent periods based on the findings of IgG and IgM antibodies for viral infections such as measles and hepatitis A. Saltik (2018) determined the periods of CDV infection in line with the antibody findings using the same method in his study. In this study, 17 (18.48\%) of the dogs sampled were positive only for IgM, 70 dogs (76.09\%) were positive for both antibodies (IgG and IgM antibodies), and four dogs (4.35\%) were found to be positive only for IgG antibodies. Based on these data, according to the evaluation method reported by Saltik (2020) and Richmann et al. (2017), 18.48\% (17/92) of the animals were in the acute phase, and $76.09 \%$ (70/92) were in the early convalescent period. It was determined that $4.35 \%(4 / 92)$ of them were in the late reconvalescent period, that is, in the last period of the disease or had the disease. However, IgM-negative and IgG-positive results may also indicate chronic infection (Esin, 2013; Saltik, 2018).

The findings that only one dog did not have CDV infection and the high persentage rate of IgM antibodies indicate that the CDV infection is acutely intense in the region and that the dogs in the region are at a serious risk of distemper. Despite the inadequacy of the study in terms of epizootiology and the lack of epizootiological data, the high number of animals infected with CDV infection that were brought to clinics and a rehabilitation center within 1 month of sampling suggests that the viral load in Antalya is high. Consequently, the incidence may be high.

In some studies conducted in Turkey, it was reported that the rate of positivity was higher in dogs with respiratory and digestive system symptoms together (Çalışkan, 2007; Saltk and Kale, 2020). Blixenkrone-Møller et al. (1993) reported that they found the most (31/46) CDV positivity in terms of conjunctivitis, respiratory and gastro-intestinal symptoms. In this study, 45.65\% (42/92) of the dogs sampled had mucopurulent discharge in the eye, 53.87\% (33/92) nasal hyperkeratosis, 25\% (23/92) 
Table 4. Frequency of clinical findings during CDV infection periods

\begin{tabular}{|c|c|c|c|c|c|c|c|c|c|}
\hline \multirow[t]{2}{*}{ Clinical Finding } & \multirow[b]{2}{*}{$\mathbf{N}$} & \multicolumn{2}{|c|}{$\begin{array}{c}\text { Acute } \\
\text { IgG-/IgM+ }\end{array}$} & \multicolumn{2}{|c|}{$\begin{array}{c}\text { Early } \\
\text { Convalescent } \\
\operatorname{lgG}+/ \operatorname{lgM}+\end{array}$} & \multicolumn{2}{|c|}{$\begin{array}{c}\text { Late } \\
\text { Convalescent } \\
\text { IgG+/IgM- }\end{array}$} & \multicolumn{2}{|c|}{$\begin{array}{l}\text { No Infection } \\
\text { IgG-/IgM- }\end{array}$} \\
\hline & & $\mathrm{n}$ & $\%$ & $\mathrm{n}$ & $\%$ & $n$ & $\%$ & $\mathrm{n}$ & $\%$ \\
\hline Eye Mucopurulent Discharge & 42 & 10 & 23.81 & 29 & 69.05 & 2 & 4.76 & 1 & 2.38 \\
\hline Nasal Hyperkeratosis & 33 & 3 & 9.09 & 29 & 87.88 & 1 & 3.03 & 0 & 0 \\
\hline $\begin{array}{l}\text { Nasal Mucopurulent } \\
\text { Discharge }\end{array}$ & 23 & 6 & 26.09 & 16 & 69.56 & 1 & 4.35 & 0 & 0 \\
\hline Cough & 12 & 1 & 8.33 & 11 & 91.67 & 0 & 0 & 0 & 0 \\
\hline Diarrhea & 8 & 1 & 12.50 & 6 & 75.00 & 1 & 12.50 & 0 & 0 \\
\hline Weakness & 6 & 1 & 1.67 & 5 & 83.33 & 0 & 0 & 0 & 0 \\
\hline Cachexia & 5 & 1 & 20 & 3 & 60 & 1 & 20 & 0 & 0 \\
\hline Flaking of the Skin & 1 & 1 & 100 & 0 & 0 & 0 & 0 & 0 & 0 \\
\hline Myoclonus & 1 & 0 & 0 & 1 & 100 & 0 & 0 & 0 & 0 \\
\hline Hair Loss & 1 & 0 & 0 & 1 & 100 & 0 & 0 & 0 & 0 \\
\hline Dermatitis Around the Eyes & 1 & 0 & 0 & 1 & 100 & 0 & 0 & 0 & 0 \\
\hline Anorexia & 1 & 0 & 0 & 1 & 100 & 0 & 0 & 0 & 0 \\
\hline Vomiting & 1 & 1 & 100 & 0 & 0 & 0 & 0 & 0 & 0 \\
\hline
\end{tabular}

$\mathrm{N}$ : Number of animals showing clinical signs out of 92 dogs. $\mathrm{n}$ : Positive animals with clinical signs

nasal mucopurulent discharge, $13,04 \%(12 / 92)$ had cough, $8.70 \%$ (8/92) diarrhea, $6.52 \%$ (6/92) fatigue, $1.09 \%(1 / 92)$ had flaking of the skin, dermatitis around the eyes, loss of appetite, vomiting, myoclonus and hair loss were observed. It was observed that the period with the highest clinical symptoms was the early convalescent period (see Table 4). It can be said that the probable cause of most of the clinical findings seen in the late convalescent period is immunosuppression due to infection and secondary infections (Saltk, 2018).

Blixenkrone-Møller et al. (1993) found positive results in 50 out of 66 specimens, and they reported that 48 of those specimens were under the age of two. In this study, it was observed that all animals brought to the rehabilitation center and clinic were aged between 2 and 12 months. Of the 92 samples collected, $3.30 \%$ (3/92) positive for antibodies were aged 2-6 months, and $96.70 \%(88 / 92)$ were aged 6-12 months. It was determined that $32.97 \%$ (30/92) of the dogs were male and $67.03 \%$ (61/92) were female. Based on previous studies (Esin, 2013; Wang et al., 2018; Dorji et al., 2020), although no difference in susceptibility according to gender was reported in the disease, in this study, the number of female dogs with infection was twice as high as that of males. Dorji et al. (2020) reported that there were no significant differences in the seroprevalence of CDV among different sexes, breeds, age classes, pet and stray dogs, and between the two study sites in Western Bhutan.

In the samples taken from the owned dogs brought to the private clinic, antigen positivity was found in $3.6 \%$ (1/28), positive in terms of $\operatorname{lgM}$ antibodies in $89.3 \%$ $(25 / 28)$ and IgG antibodies in $75 \%(21 / 28)$. While antigen positivity was found at a rate of $6.25 \%(4 / 64)$ in 64 dogs in the rehabilitation center, it was determined that they were $96.88 \%$ (62/64) positive for IgM antibodies and $82.81 \%(53 / 64)$ for IgG antibodies. The spread of CDV is primarily shaped by inhalation (Benieke et al., 2009). The severity of the disease, mortality and morbidity rates vary depending on the body's immune system and secondary infections. Especially in animal shelters with collective living conditions, a more suitable environment is created for the spread of the disease (Şahna et al., 2008). In the study, it is seen that the infection is quite intense in animals in shelters and street conditions. Since animals kept in rehabilitation centers and animal shelters are exposed to infection more frequently, they have an increased epizootiological risk as a source of viruses for both stray animals and domestic dogs after they are released into their natural environment. These centers play an important role in the spread of infectious diseases among animals. Animals with acute infections have a very high risk of transmitting the virus through saliva, feces, or aerosols. In the study, it can be said that stray and owned animals are at the same risk. Pets are always in contact with the street, and there is a possibility of contact with stray animals in order to meet the need for walking and toileting on the street. Therefore, there is always the risk of getting the virus. Since stray animals are unvaccinated and the virus is constantly circulating in them, they are in the position of a reservoir and pose 
a potential risk to pets. For this reason, it is thought that establishing control programs against CDV and regularly vaccinating all dogs with and without owners living in city centers can minimize distemper-related losses. However, it is not currently feasible, either logistically or economically, to vaccinate all stray dogs. Therefore, it may be advisable to keep dogs at home, especially in the first phase, and only release them after they have been vaccinated against CDV. In addition, in order to prevent the spread of infectious diseases, it is necessary to develop control programs such as adopting stray dogs, neutering them, and improving the hygiene and management of shelters.

Due to their easy application in veterinary medicine and rapid results, immunochromatographic imaging systems, also called rapid tests, have become a highly preferred method. It is very practical and useful because the treatment protocol is quickly formed after simple and fast results are obtained and the diagnosis is made. Although the sensitivity and specificity of the rapid test are low, this test can be performed quickly before performing RT-PCR, electron microscopy, virus isolation, immunofluorescence, and ELISA tests due to its practicality (Elia et al., 2006). But in this study, the rate of antigen positivity with rapid testing was found to be very low $(5.43 \%)$.

Wang et al. (2018) tested 32 nasal swab samples from clinically suspicious dogs with a rapid test kit and found $62 \%$ positivity. They also obtained the same results in their comparison with RT-PCR. Esin (2013) reported that 45 of the eye swabs collected from a total of 116 clinically suspicious animals were positive. Vivaldo (2019) reported that $54 \%$ positivity in ocular fluids, $51 \%$ in urine, and $46 \%$ in blood were observed in 141 dogs in his study. He reported that positivity was $62 \%$ by ELISA, $46 \%$ by the immunochromatographic method, and $95 \%$ by RT-PCR. In this study, positive results were obtained in $5 / 92(5.4 \%)$ of the rapid antigen tests performed on blood serum. The reason for the low rates in the rapid antigen test may be the use of a serum sample instead of a conjunctival swab sample and the low amount of antigen in the circulation due to the formed antibodies. It is thought that this rate may be higher if it is done with tear samples. Due to the results obtained in this study, the availability of immunochromatographic rapid test methods in CDV diagnosis using different diagnostic materials (blood, serum, tears, saliva, etc.) should be investigated. In addition, it may be recommended to check the specificity and sensitivity of the rapid tests at periodic intervals, considering the antigenic variability of the virus, time, and geographical location.

\section{Conclusion}

As a result of this study, it was observed that an acute CDV infection was common in dogs in Antalya when the sampling was done, and an probably intense virus load was circulating in the region. It has been concluded that the infection poses the same risk to free-running dogs on the street, both stray and owned dogs. It has been observed that the rate of infected female animals is twice that of males, and it is frequently encountered in animals under one year old. Based on the results of this study, although epidemiological data is scarce, it is estimated that the incidence and prevalence of CDV infection may be high. In addition, it was observed that clinical findings of CDV infection were more intense in the early reconvalescent period.

Consequently, study data suggests that strategies to combat CDV infections need to be developed and strictly implemented. For this, more research on CDV's epizootiology (incidence, prevalence, host characteristics) and virological properties (genetic variability of the virus, the success of antibodies against vaccinia virus in protecting against existing strains in the region, the relationship between pathogenesis and field isolates, etc.) is needed.

\section{Acknowledgements}

This study was supported by Foundation of Scientific Research Projects of the Aydin Adnan Menderes University with project number VTF-18020. The paper was summarized from a Master's thesis of the first author.

\section{Conflict of interest}

The authors declare that they have no conflict of interest in this study.

\section{References}

Appel, M.J.G., \& Summers, B.A. (1999). Canine distemper: Current Status. Recent Advances in Canine Infectious Diseases. https:// www.ivis.com.

Barrett, T. (1999). Morbillivirus infections with special emphassis on morbilliviruses of carnivores. Veterinary Microbiology, 69, 3-13. https://doi.org.10.1016/s0378-1135(99)00080-2

Blixenkrone-Møller, M., Svansson, V., Have, P., Orvell, C., Appel, M., Rode Pedersen, I., \& Henriksen, P. (1993). Studies on manifestations of canine distemper virus infection in an urban dog population. Veterinary Microbiology, 37(1-2), 163-173.

Çalışkan, E. (2007). Köpek Gençlik Hastalığı Virus İzolasyonu, H Proteini kodlayan gen bölgesinin karakterizasyonu ve seroepidemiyolojisi, Doktora Tezi, Ankara Üniversitesi, Sağlık Bilimleri Enstitüsü, Ankara.

Çalışkan, E., \& Burgu, I. (2007). Köpek gençlik hastalığı virusunun prevalansı ve seroepidemiyolojisi. Veterinary Microbiology, 18, 5-10.

Dorji, T., Tenzin, T., K. Tenzin, K., Tshering, D., Rinzin, K., Phimpraphai, W., \& de Garine-Wichatitsky, M. (2020). Seroprevalence and risk factors of canine distemper virus in the pet and stray dogs in $\mathrm{Haa}$, western Bhutan. BMC Veterinary Research, 16, 135. https://doi. org/10.1186/s12917-020-02355-x.

Elia, G., Camero, M., Losurdo, M., Lucente, M. S., Larocca, V., Martella, V., Decaro, N., \& Buonavoglia, C. (2015). Virological and serological findings in dogs with naturally occurring distemper. Journal of Virological Methods. 213, 127-130.

Esin, E. (2013). Köpeklerde Canine Distemper Virus Enfeksiyonun Araştırılması, Doktora Tezi, Konya Selçuk Üniversitesi, Sağlık Bilimleri Enstitüsü, Konya.

ICTV (2020). International Committee on Taxonomy of Viruses. https:// talk.ictvonline.org/taxonomy/(accessed 20 August 2021).

Latha D., Geetha M., Ramadass., P., \& Narayanan, R.B. (2007a). Development of recombinant nucleocapsid protein based IgMELISA for the early detection of distemper infection in dogs. 
Veterinary Immunology and Immunopathology, 119, 278-286. https://doi.org.10.1016/j.vetimm.2007.06.006

Latha, D., Srinivasan, S.R., Thirunavukkarasu, P.S., Gunaselan, L., Ramadass, P., Narayanan, R.B. (2007b). Assessment of canine distemper virus infection in vaccinated and unvaccinated dogs. Indian Journal of Biotechnology, 6, 35-40.

Richmann, D.D., Whitley R.J., \& Hayden, F.G. (2017). Clinical virology, $4^{\text {th }}$ edition, American Society for Microbiology. Washington, 1489.

Sabatino, D. (2016). Lethal distemper in badgers (Meles meles) following epidemic in dogs and wolves, Infection, Genetics and Evolution, 46,130-137.

Saltk, H.S.(2018). Klinik semptomlu köpeklerin kan, idrar, rektal sürüntü, nasal ve oküler akınt örneklerinde canine distemper virus enfeksiyonun real time RT-PCR ile tespit edilmesi. Doktora Tezi, Mehmet Akif Ersoy Üniversitesi, Sağlık Bilimleri Enstitüsü, Burdur.

Saltik, H.S., \& Kale, M. (2020). Evaluation of infection with N proteinspecific Immunoglobulin $M$ and $\mathrm{G}$ in naturally occurring distemper in dogs. Veterinarni Medicina, 65, 2020 (04), 168-173. https://doi. org/10.17221/31/2019-VETMED.

Şahna, K.C., Gençay, A., \& Atalay, O. (2008). Viral etilogy of diarrhoea in puppies from a same shelter in turkey, presence of mixed infections. Revue de Médecine Vétérinaire, 159, 345-347.

Von Messling, V., Harder, T.C., Moennig, V., Rautenberg, P., Nolte, I., \& Haas, L. (1999). Rapid and sensitive detection of Immunoglobulin $\mathrm{M}$ (IgM) and IgG antibodies against canine distemper virus by a new recombinant nucleocapsid protein-based enzyme-linked immunosorbent assay. Journal of Clinical Microbiology, 37(4), 1049-1056.

Wang, J., Li, R., Shi, R., Liu, L., \& Yuan, W. (2018). Evaluation of an incubation instrument-free reverse transcription recombinase polymerase amplification assay for rapid and point-of-need detection of canine distemper virus. Journal of Virological Methods, 260, 56-61. https://doi.org.10.1016/jviromet.2018.07.007

Zacarias, J., Dimande, A., Achá, S., Dias, P.T., Leonel, E.M., Messa A., Macucule, B., Júnior, J.L., \& Bila, C.G. (2016). Severe canine distemper outbreak in unvaccinated dogs in Mozambique. Juorna of South African Veterinary Association, 87(1), 1350. https://doi: 10.4102/jsava.v87i1.1350 